\title{
ARDL models of Military Spending and its Security and Economic Determinants
}

\author{
Jiř́ NEUBAUER ${ }^{1}$, Jakub ODEHNAL ${ }^{2}$
}

${ }^{1}$ Department of econometrics, University of Defence in Brno, Kounicova 65, 66210 Brno, Czech

Republic

${ }^{2}$ Department of economics, University of Defence in Brno, Kounicova 65, 66210 Brno, Czech

Republic

E-mails: ${ }^{1}$ jiri.neubauer@unob.cz; ${ }^{2}$ jakub.odehnal@unob.cz

\begin{abstract}
This contribution deals with modelling of military expenditure and its potential security and economic determinants by an Autoregressive Distributed Lag (ARDL) model. This approach is applied to several NATO member countries over the period 2001-2016, namely to Visegrad group countries and Baltic states. Time series of military expenditure (database SIPRI), the risk of inflation, GDP growth, terrorism, foreign pressure, cross-border conflict and ethnic tension (database of Political Risk Service Group) are used in analysis.
\end{abstract}

KEY WORDS: military expenditure, security determinants, economic determinants, ARDL model

\section{Introduction}

The NATO countries represent political and military Alliance covers 29 members. From the long-term point of view, only a small group of the 29 countries fulfills the recommended values of allocating $2 \%$ of GDP at a minimum in favor of defense. The issue of military spending and its link to economic variables, political stability or other country characteristics is still intensively discussed in defense economic literature, see for example [1], [2], [3] or [4]. This paper has provided an empirical analysis of the determinants of military spending in the selected NATO countries for the period from 2001 to 2016. Empirical studies [5], [6] aimed at identifying military expenditure determinants classify those determinants into groups of economic factors, political factors and strategic factors. The first group of variables, marked as economic factors contains variables like the amount of GDP per inhabitant, GDP growth and fiscal variables. The political factors include variables like the quality of democracy, voting system, form of government, ideology and finally, strategic factors cover variables describing security environment by civilian war risks, terrorism risk and by previous participation of countries in armed conflicts and participation of the country in a certain type of Alliance. We focus on modeling military expenditure in following 7 countries: Visegrad group countries (Czech Republic, Slovak Republic, Hungary and Poland) and Baltic states (Estonia, Latvia and Lithuania). Data from database SIPRI (Stockholm International Peace Research Institute) and PRS (Political Risk Service Group) are used. The aim of the contribution is to describe the development of military expenditure (a percentage of GDP) by selected economic and security determinants, such as a risk for inflation, a risk for GDP per capita, a risk for foreign debt, a risk for terrorism and a risk for foreign pressures.

\section{The Mathematical Background}

We analyze data from 2001 to 2016. Time series under scope are too short for applying a vector autoregressive model, or a vector error correction model [7]. We employ autoregressive distributed lag model ARDL(p,q1,q2,..,qk), where $\mathrm{p}$ is the number of lags of the dependent variable $Y_{t}, q_{1}, q_{2}, \ldots, q_{k}$ are numbers of lags of explanatory variables $X_{i t}$, $i=1,2, \ldots, k$. The model can be written as

$$
Y_{t}=\alpha+\sum_{i=1}^{p} \gamma_{i} Y_{t-i}+\sum_{j=1}^{k} \sum_{i=0}^{q_{j}} \beta_{j, i} X_{j, t-i}+\varepsilon_{t}
$$

where $\varepsilon_{t}$ is a one-dimensional zero mean error term. It is possible to transform the model into a long-run representation showing the long run response of the dependent variable to a change in the explanatory variables. The long run estimates are given by [7], [8]. 


$$
\hat{\theta}_{j}=\frac{\sum_{i=1}^{q_{j}} \hat{\beta}_{j, i}}{1-\sum_{i=1}^{p} \hat{\gamma}_{i}} .
$$

The ARDL approach offers except for the dynamic description also testing of cointegration. The cointegrated system of time series can by estimated as ARDL model (Pesaran and Shin, 1999) with the advantage that variables in cointegrating relationship can be either $I(0)$ or $I(1)$ without needing to specify which are $I(0)$ or $I(1)$. For the purpose of cointegration analysis the form of (1) in differences is used

$$
\begin{aligned}
& \Delta Y_{t}=\sum_{i=1}^{p-1} \gamma_{i}^{*} \Delta Y_{t-i}+\sum_{j=1}^{k} \sum_{i=0}^{q_{j}-1} \beta_{j, i}^{*} \Delta X_{j, t-i} \\
& -\hat{\phi} E C_{t-1}+\varepsilon_{t},
\end{aligned}
$$

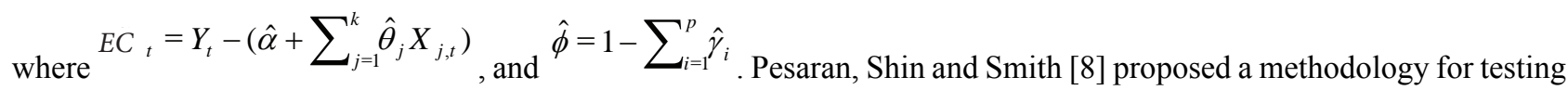
existence of long-run relationship between independent variable and regressors. For so called bounds testing they use the following representation of (3)

$$
\begin{aligned}
& \Delta Y_{t}=\sum_{i=1}^{p-1} \gamma_{i}^{*} \Delta Y_{t-i}+\sum_{j=1}^{k} \sum_{i=0}^{q_{j}-1} \beta_{j, i}^{*} \Delta X_{j, t-i} \\
& -\rho Y_{t-1}-\alpha-\sum_{j=1}^{k} \delta_{j} X_{j, t-1}+\varepsilon_{t} .
\end{aligned}
$$

The test for existence of long-run relationship is a test of $\rho=0$ and $\delta_{1}=\delta_{2}=\ldots=\delta_{k}=0$. The distribution of the test statistic based on (4) depends on the fact whether the regressors are $I(0)$ or $I(1)$. Pesaran, Shin and Smith [8] provide critical values for the cases where all regressors are $I(0)$ and the cases where all regressors are $I(1)$. These critical values are used as bound for the more typical cases where the regressors are a mixture of $I(0)$ and $I(1)$.

\section{Empirical Results}

Military expenditure (as a percentage of GDP) of the Czech Republic, Slovakia, Poland, Hungary, Estonia, Latvia and Lithuania is shown in Fig. 1. One can see significant decrease of military expenditure in the Czech Republic, Slovakia and Hungary. In Poland and Estonia, a level of military spending is around the recommended level 2\%. Military expenditure has been increasing in recent years in Baltic States.
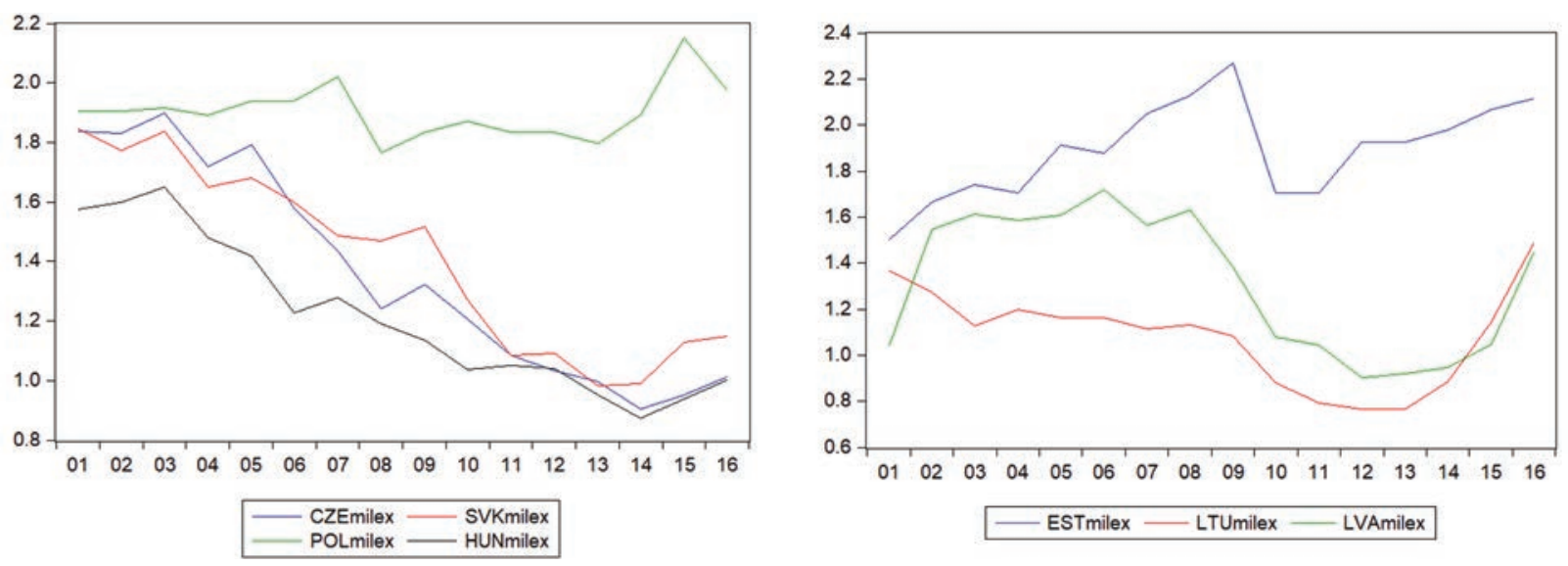

Fig. 1. Military expenditures (as a percentage of GDP) of V4 and Baltic states

In Figure 1 illustrating the development of military expenditure of analyzed V4 and Baltic states after 2001, a significant decrease in military expenditure caused especially by the effect of economic crisis can be observed (with exception of Poland). Poland is an example both as a country with a responsible policy of allocating 1.95 percent of last year's GDP to defense and compared to many other European countries not being hurt by the economic crisis. The result of government policy is an allocation of military expenditure between 1.7 and 2 percent of GDP in the analyzed period. 
In spite of the reduction of Czech, Slovak and Hungarian military expenditure after 2002 we can observe increasing trend after 2014 as a result of NATO Summit in Wales. In the case of Latvia, we can observe decreasing of military expenditure in the period 2008 and 2012 as a result of economic policy aimed for having stable public finances as a part of the euro convergence criteria. Similar factor affecting military expenditure we can identify in Lithuania, where joining the Eurozone was a key priority of the government. Rapid increasing of Lithuanian and Latvian military expenditure we can see after 2014. Estonian military expenditure was reduced in 2010, it has increased since 2011 again and now Estonia met this 2 percent target. Generally, determinants of military expenditure of V4 and Baltic states as a new NATO member states were influenced both by a number of political and economic factors in the early nineties leading to transformation of society and national economies and by military factors (e.g. transfer to the professional army systems, modernization of armies, participation of V4 and Baltic states in foreign operations).

To quantify the determinants of military expenditure, the authors selected data from the database of Political Risk Service Group (PRS) defining economic, security and political risks of the respective countries. In order to analyze economic environment as a determinant of military expenditure, the following variables were monitored: foreign debt as a percentage of GDP, risk of inflation, economic condition measured by the GDP. For security risk analysis, the following variables were used: risk of terrorism, and risk of foreign pressures. Actual variables contained in the database are further observed for analytical purposes on the scale shown below in Table 1 . Therefore, lower values of these variables are interpreted as higher economic, security or political risks.

Table 1

Description of variables

\begin{tabular}{|c|c|c|}
\hline Variables & Description & Measurement \\
\hline $\begin{array}{l}\text { Foreign Debt as a } \\
\text { Percentage of GDP }\end{array}$ & $\begin{array}{l}\text { The estimated gross foreign debt in a given } \\
\text { year, is expressed as a percentage of the GDP. }\end{array}$ & $\begin{array}{l}\text { e.g. } 0 \text { to } 4.9,10 \text { points, } 5 \text { to } 9.9,9.5 \text { points } \\
\text { and } 200 \text { plus, } 0 \text { points }\end{array}$ \\
\hline GDP per Capita & $\begin{array}{l}\text { The estimated GDP is expressed as } \\
\text { a percentage of the average of the estimated } \\
\text { total GDP of all the countries. }\end{array}$ & $\begin{array}{l}\text { e. g. } 250 \text { plus ( } \% \text { of average), } 5 \text { points, } 200 \\
\text { to } 249.99,4.5 \text { points and e.g. up to } 9.9,0 \\
\text { points }\end{array}$ \\
\hline Inflation & $\begin{array}{l}\text { The estimated annual inflation rate (the } \\
\text { unweighted average of the Consumer Price } \\
\text { Index) is calculated as a percentage change. }\end{array}$ & $\begin{array}{l}\text { e.g. } 130 \% \text { change plus, } 10 \text { points, } 2.0 \\
\text { below, } 0 \text { points }\end{array}$ \\
\hline Foreign Pressures & $\begin{array}{l}\text { A score of } 4 \text { points equates to Very Low Risk } \\
\text { and a score of } 0 \text { points to Very High Risk. }\end{array}$ & $\begin{array}{l}\text { Maximum score of four points and } \\
\text { a minimum score of } 0 \text { points. }\end{array}$ \\
\hline Terrorism & $\begin{array}{l}\text { A score of } 4 \text { points equates to Very Low Risk } \\
\text { and a score of } 0 \text { points to Very High Risk. }\end{array}$ & $\begin{array}{l}\text { Maximum score of four points and } \\
\text { a minimum score of } 0 \text { points. }\end{array}$ \\
\hline
\end{tabular}

Firstly, we estimate parameter of ARDL model (1) for all 7 countries. Considering the length of analyzed time series, we apply only lag 1 in the models. Table 2 contains statistically significant parameters of estimated models (at the significance level 0.05). For example, the model for the Czech Republic is of the form

$$
\begin{aligned}
& \text { Milex }_{t}=0.492 \text { Milex }_{t-1}+0.026 \text { Inflation }_{t} \\
& -0.158 \text { Inflation }_{t-1}+0.550 \text { Foreign pressures } \\
& t
\end{aligned}
$$

ARDL model parameter estimates - V4 and Baltic states

\begin{tabular}{|c|c|c|c|c|c|c|c|}
\hline Variable & CZE & SVK & POL & HUN & EST & LVA & LTU \\
\hline Milext-1 & 0.492 & 2.871 & -0.349 & 0.730 & 0.512 & 0.273 & 0.415 \\
\hline Inflationt & 0.026 & 0.796 & 0.102 & -0.054 & -0.189 & 0.191 & \\
\hline Inflationt-1 & -0.158 & -0.244 & 0.175 & 0.077 & & & \\
\hline GDPt & & -1.360 & & & & & -0.248 \\
\hline GDPt-1 & & 0.402 & & & & & -0.326 \\
\hline Debtt & & -1.155 & 0.066 & & 0.207 & 0.169 & 0.183 \\
\hline Debtt-1 & & 0.482 & & & & 0.234 & -0.341 \\
\hline Terrorismt & & -0.685 & 0.404 & -0.015 & & -1.796 & -0.813 \\
\hline Terrorismt-1 & & 1.676 & -0.120 & -0.349 & & 1.041 & 0.090 \\
\hline Foreign pressurest & 0.550 & 0.464 & & & -2.416 & -4.252 & \\
\hline Foreign pressurest-1 & & 0.473 & & & -0.699 & 0.690 & \\
\hline Const. & 0.130 & -8.501 & -1.263 & 1.504 & 10.107 & 11.973 & 5.673 \\
\hline $\mathrm{R}^{2}$ & 0.970 & 0.997 & 0.867 & 0.958 & 0.809 & 0.986 & 0.983 \\
\hline
\end{tabular}


Estimated parameters of the error correction form (2) of ARDL model are summarizes in Table 3, the coefficients of long run relationship are in Table 4. For example, the long run relationship for the Czech Republic is estimated as

$$
\begin{aligned}
& \hat{E} C_{t}=\text { Milex }_{t}- \\
& \left(-0.260 \text { Inflation }_{t}+1.081 \text { Foreign pressures }_{t}+0.257\right)
\end{aligned}
$$

The existence of long-run level relationship can be verified by so calle F-bound test in the model (4). The results are shown in Table 5. At the significance level 0.05 , we can reject the null hypothesis that there is no level relationship in all anlyzed countries except for Hungary. The test statistic value is close to the critical value for $I(1)$ processes. The null hypothesis can be rejected at the significance level 0.10. In the Czech Republic, increase in variable Inflation (the increase means lower risk) is linked to the decrease of military expenditure. On the other hand, the increase in variable Foreign pressures is connected to the increase of military expenditure.

The outcome of the ARDL model (long run) described in Table 3 identifies 5 statistically significant variables (Inflation, GDP, Debt, Terrorism, and Foreign Pressures). In the case of the Inflation, it is possible to observe the negative link between the risk and the amount of military expenditure identifying the decline in military expenditure in the event of a decrease in Inflation in the case of the Czech Republic, Slovakia and Estonia. A positive link can be seen in the case of Poland, Hungary and Latvia. The result of the GDP per Capita Risk analysis is the positive link between GDP per Capita Risk and military spending in the case of Slovakia (indicates that military expenditure is increasing due to a favorable economic situation) and the negative link in the case of Lithuania. For most of the V4 and Baltic states (for the Czech Republic and Hungary the coefficients are not significant), there is a significant positive effect of Risk for Foreign debt on military expenditure suggesting that decreases in risk lead to increases in military expenditures. The only countries where foreign debt has a negative link to military expenditure is Lithuania. In the case of the Risk of terrorism, it is possible to observe the negative link between the risk and the amount of military expenditure identifying the decline in military expenditure in the event of a decrease in Risk of terrorism in the case of Slovakia, Hungary, Latvia, Lithuania and positive link in the case of Poland. Finally, the link between Risk of Foreign Pressures and military expenditure is really important in the case of Estonia and Latvia $(-6,385$ and -4.900$)$ and indicates that increasing of value (lower risk) probably leading to lower military expenditure. The similar negative link we can observe in the case of Slovakia, the positive link in the case of the Czech Republic.

Table 3

\begin{tabular}{|c|c|c|c|c|c|c|c|}
\hline Variable & $\mathrm{CZE}$ & SVK & POL & HUN & EST & LVA & LTU \\
\hline$\Delta$ Inflationt & 0.026 & 0.796 & 0.102 & -0.054 & & & \\
\hline$\Delta \mathrm{GDPt}$ & & -1.360 & & & & & -0.248 \\
\hline$\Delta$ Debtt & & -1.155 & & & & 0.169 & 0.183 \\
\hline$\Delta$ Terrorismt & & -0.685 & 0.404 & -0.015 & & -1.796 & -0.812 \\
\hline$\Delta$ Foreign pressurest & & 0.464 & & & -2.416 & -4.252 & \\
\hline ECt-1 & -0.508 & 1.871 & -1.349 & -0.270 & 0.488 & -0.727 & -0.585 \\
\hline
\end{tabular}

ARDL model parameter estimates (short run) - V4 and Baltic states

ARDL model parameter estimates (long run) - V4 and Baltic states

\begin{tabular}{llllllll}
\hline \multicolumn{1}{c}{ Variable } & CZE & SVK & POL & HUN & EST & LVA & LTU \\
\hline Inflationt & -0.260 & -0.295 & 0.206 & 0.088 & -0.387 & 0.262 & \\
GDPt & & 0.512 & & & & & -0.981 \\
Debtt & & 0.360 & 0.049 & & 0.425 & 0.555 & -0.270 \\
Terrorismt & & -0.529 & 0.210 & -1.346 & & -1.039 & -1.235 \\
Foreign pressurest & 1.083 & -0.501 & & & -6.385 & -4.900 & \\
Const. & 0.257 & 4.544 & -0.936 & 5.567 & 20.717 & 16.470 & 9.695 \\
\hline
\end{tabular}

F-bound test - V4 and Baltic states (at significance level 0.05)

Table 5

\begin{tabular}{lccccccc}
\hline & CZE & SVK & POL & HUN & EST & LVA & LTU \\
\hline Test statistic & 5.63 & 15.24 & 13.74 & 3.81 & 7.72 & 24.46 & 20.56 \\
Degrees of freedom & 2 & 5 & 3 & 2 & 3 & 4 & 3 \\
Critical value I(0) & 3.10 & 2.39 & 2.79 & 3.1 & 2.79 & 2.56 & 2.79 \\
Critical value I(1) & 3.35 & 3.38 & 3.67 & 3.87 & 3.67 & 3.49 & 3.67 \\
\hline
\end{tabular}



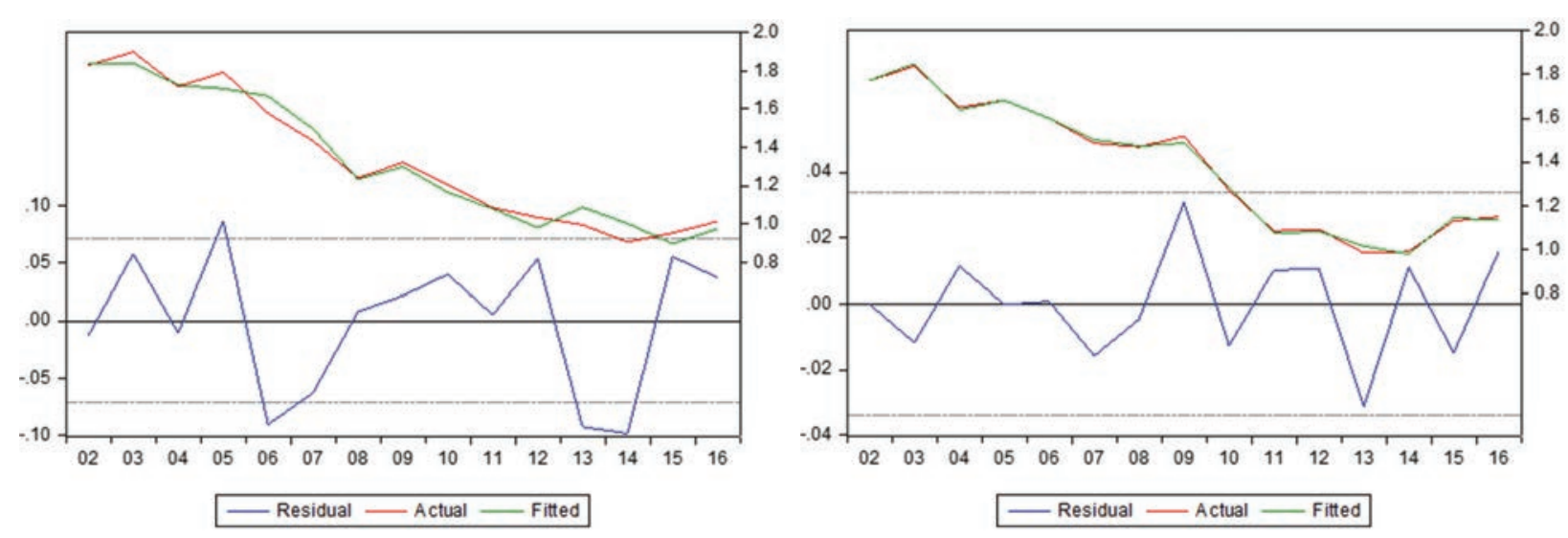

Fig. 2. ADRL models of military expenditure (as a percentage of GDP) - Czech Republic (left), Slovakia (right)
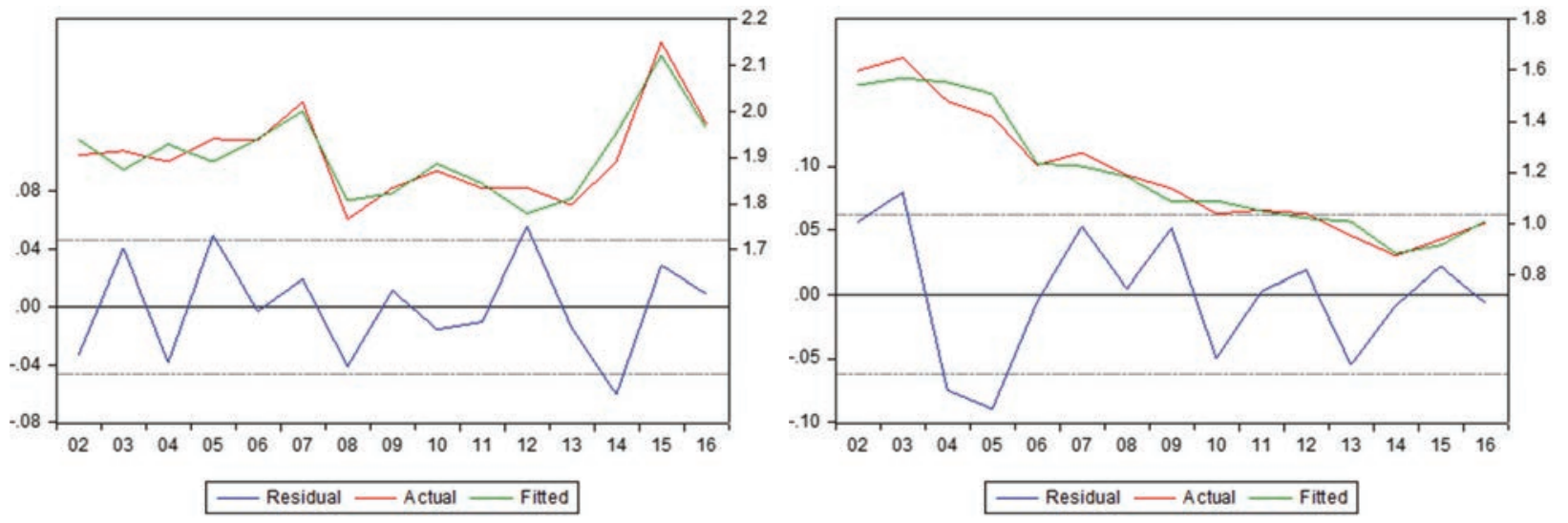

Fig. 3. ADRL models of military expenditure (as a percentage of GDP) - Poland (left), Hungary (right)
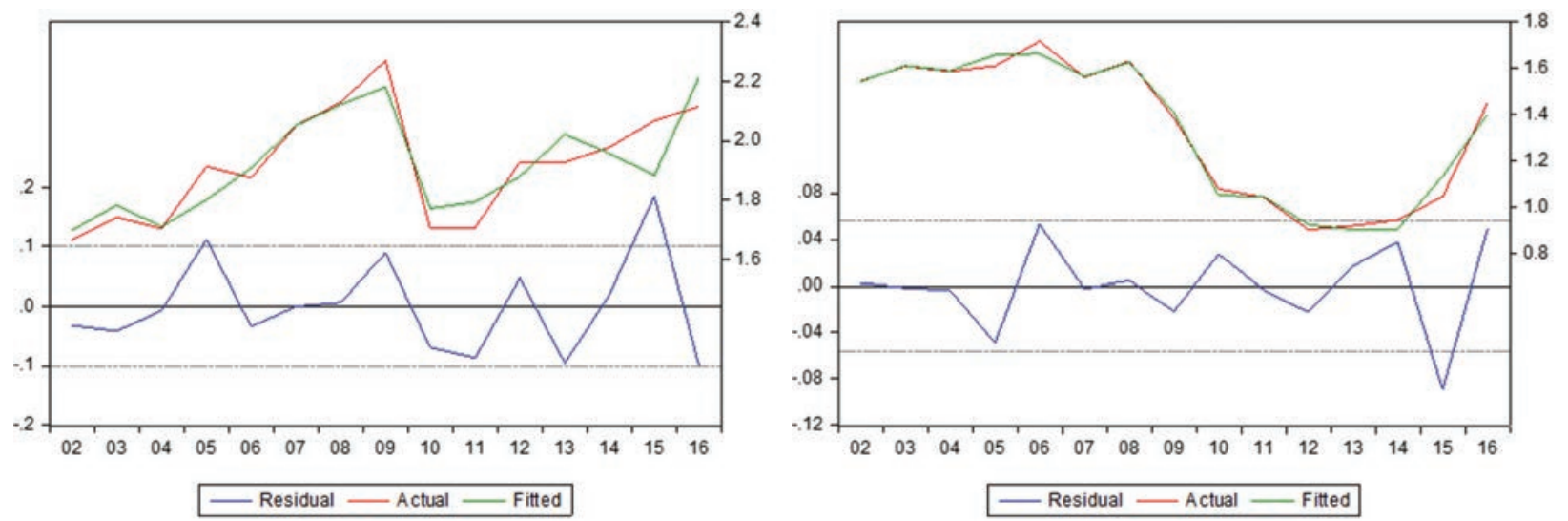

Fig. 4. ADRL models of military expenditure (as a percentage of GDP) - Estonia (left), Latvia (right)

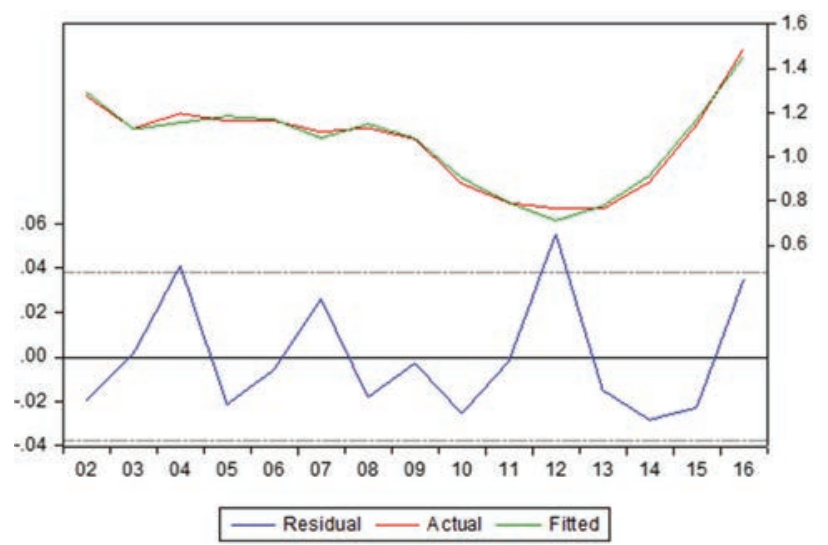

Fig. 5. ADRL models of military expenditure (as a percentage of GDP) - Lithuania 


\section{Conclusions}

The contribution presents application of the autoregressive distributed lag model to identify possible determinant of military expenditure in the Visegrad group countries and the Baltic States. The aim of the autoregressive distributed lag model is to describe analyzed time series of military expenditures and describe the relationship with other regressors, such as a risk for inflation, a risk for GDP per capita, a risk for foreign debt, a risk for terrorism and a risk for foreign pressures. The outcomes of the analysis show that military expenditures are strongly correlated with their previous values and also indicate that there is very little uniformity in the factors that determine military expenditure in the Visegrad group countries and the Baltic States. Finally, the results revealed strong correlation between the risk for foreign pressures and military expenditures in the case of Estonia and Latvia as a result of current security situation and defense policy in the Baltic States.

\section{Acknowledgements}

This contribution was supported by FML Development Project AERO.

\section{References}

1. Topcu, M, Aras, İ. Military Expenditures and Economic Growth in Central and Eastern EU Countries: Evidence from the Post-Cold War Era. European Review, 2017, 25(3), p. 453-462.

2. George, J., Sandler, T. Demand for Military Spending in NATO, 1968-2015: A Spatial Panel Approach. European Journal of Political Economy, 2017, Retrieved 19.11.2017 from

3. https://doi.org/10.1016/j.ejpoleco.2017.09.002.

4. Holcner, V, Olejníček, A. Possibilities of Defense Spending Stabilization. Journal of Security Sustainability Issues, 2017, 7(1), p. 5-16.

5. Odehnal, J., Neubauer, J. Economic Determinants of Military Spending - Causal Analysis. Ekonomický časopis, 2015, 63(10), p. 1019-1032.

6. Sezgin, Y, Yildrim, J. The Demand for Turkish Defence Expenditure. Defence and Peace Economics, 2002, 13(2), p. 121-128.

7. Dunne, P, Nikolaidou, E. Military expenditure and economic growth: A demand and supply model for Greece, 1960-1996. Defence and Peace Economics, 2001, 12 (1), p. 47-67.

8. Pesaran, M H, Shin, Y. An Autoregressive Distributed Lag Modelling Approach to Cointegration Analysis. In Econometrics and Economic Theory in the 20th Century: The Ragnar Frisch Centennial Symposium, edited by S. Strom, Cambridge: Cambridge University Press, 1999.

9. Pesaran, M H, Shin, Y, Smith, R J. Bounds Testing Approaches to the Analysis of Level Relationships. Journal of Applied Econometrics, 2001, 16, p. 298-326. 